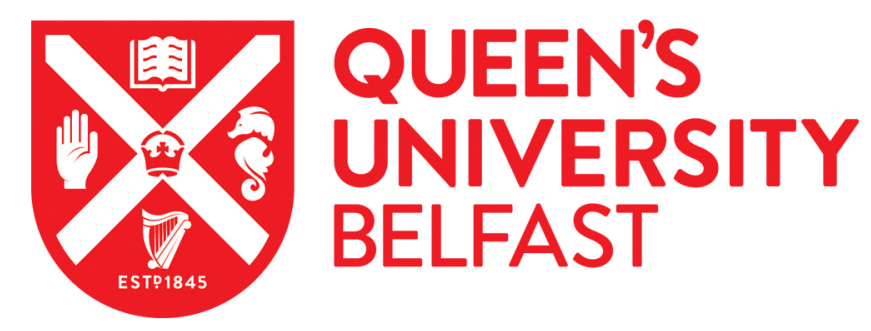

\title{
The Shakespearean Auteur and the Televisual Medium
}

Wray, R. (2016). The Shakespearean Auteur and the Televisual Medium. Shakespeare Bulletin, 34(3), 469-485. https://doi.org/10.1353/shb.2016.0037

\section{Published in:}

Shakespeare Bulletin

\section{Document Version:}

Publisher's PDF, also known as Version of record

Queen's University Belfast - Research Portal:

Link to publication record in Queen's University Belfast Research Portal

\section{Publisher rights}

(C) 2016 The Johns Hopkins University Press. This article first appeared in Shakespeare Bulletin, Volume 34, Issue 3,

September, 2016, pages 469-485.

\section{General rights}

Copyright for the publications made accessible via the Queen's University Belfast Research Portal is retained by the author(s) and / or other copyright owners and it is a condition of accessing these publications that users recognise and abide by the legal requirements associated with these rights.

Take down policy

The Research Portal is Queen's institutional repository that provides access to Queen's research output. Every effort has been made to ensure that content in the Research Portal does not infringe any person's rights, or applicable UK laws. If you discover content in the Research Portal that you believe breaches copyright or violates any law, please contact openaccess@qub.ac.uk. 


\section{PROJECT MUSE}

\section{The Shakespearean Auteur and the Televisual Medium}

Ramona Wray

Shakespeare Bulletin, Volume 34, Number 3, Fall 2016, pp. 469-485 (Article)

Published by Johns Hopkins University Press

DOI: 10.1353/shb.2016.0037

$\Rightarrow$ For additional information about this article https://muse.jhu.edu/article/629793 


\title{
The Shakespearean Auteur and the Televisual Medium
}

\author{
Ramona Wray \\ Queen's University, Belfast
}

$\mathcal{T}_{\mathrm{r}}$

raditionally, auteur theory has not been deployed in relation to television. As Rosalind Coward writes, summarizing a general consensus at the end of the twentieth century, to "study" the "author" is seen as "a peculiarly limiting way of approaching ... the collective productions of ... television," a medium which evokes "industrial production" rather than "the literary image of an individual author or artist" (7). As a collaborative mode of production characterized by a range of skills, responsibilities, and forms of labor, television is generally seen as unsuited for any type of appreciation that emphasizes a unitary artistic imprimatur. Undoubtedly, a certain snobbery inheres in such a judgement. The concept of the auteur was introduced in part, as Robert Stam argues, to support "cinema's search for artistic legitimation," to elevate the institution as an art-form (1). And, even today, auteur theory often comes to the rescue in differentiating between "art" and so-called mass entertainment. Television has long been viewed as a lesser representational medium; tarnished with a down-market association, it is not deemed worthy of auteurial identifiers.

Yet this view is beginning to be adjusted as television undergoes a fundamental shift. Television programming is now subject to markedly different production methods and, as Brett Martin notes, many recent series are characterized by sophisticated technologies, including an extensive use of "shadows and darkness; hypnotic depth of field; beautiful, endless wide-shots; [and] handheld pyrotechnics" (15). In many respects, these newer television creations rival-even go beyond-standard cinema in scope, length and character development, as dramas such as The Sopranos, Mad Men, and True Detective, demonstrate. Indeed, a current and widely-shared assessment posits the television show as no less than "the signature American art form of ... the twenty-first century" (Martin 11). 
Inevitably, then, in the light of such developments, those involved in the production of television are regarded more affirmatively.

As particular shows have come to prominence, so have the makers of those shows, a recent argument being that the self-consciously artistic features of television can be traced to the creativity of an individual practitioner. But, unlike traditional cinema criticism, which has tended unproblematically to align the director and the auteur, understandings of television, not least because of the medium's more complex working mechanisms, require a more generous conception of the auteur and his/ her operations. One newer understanding centers on the role of the "showrunner," defined according to the $O E D$ as the individual with "overall creative authority and management responsibility for a television programme" (def. 2). Colin Robertson describes the "showrunner" as the "auteur of the small screen" (n. pag.), and, certainly, the commercial success of shows like Breaking Bad, Homeland, and The Wire has lent a particular visibility and kudos to some television creatives. Nor does the change in attitude necessarily reflect a big-budget or male phenomenon. While most television auteurs are men, small-budget shows such as Girls, created by and also starring Lena Dunham, announce the significant involvement of women while playing up the thematics of "authorship" as crucial to their possibility.

This essay explores what understandings of the auteur might mean for a new era of television Shakespeare. Four films purposefully crafted to form a core component of the cultural Olympiad, The Hollow Crown stands par excellence as an example of "event television." Closely allied to the 2012 Olympic Opening Ceremony, the subsequent Olympics and the Diamond Jubilee, the series illustrates the uses to which television Shakespeare can be put at times of celebration and the vital part that Shakespeare continues to play in debates around culture, community, and identity. An international co-production (the BBC joined forces with Neal Street Productions, NBC Universal, and WNET Thirteen) produced for a multinational audience, and the winner of prestigious awards, The Hollow Crown is indicative of the standards that contemporary television can attain in terms of aesthetic achievement. The Hollow Crown's status as "quality television" is indicated in its high production values and technical accomplishment. Produced by Sam Mendes, this television project is characterized by a feature-film appearance (the series is shot to suggest a glossy and high definition "look"), a budget of tens of millions, and a stellar cast. Exemplary of how television is made at the present juncture, The Hollow Crown needs to be investigated in relation to the most recent understandings of the medium. 
As producer, Mendes was central to raising the money for The Hollow Crown. This was not a straightforward process, and a particular stumbling-block came when BBC Worldwide decided against contributing to the production costs, despite BBC2's prior commitment of funds (see Brown n. pag.). Accordingly, Mendes was forced to find an alternative source of support, finally convincing NBC Universal that the Shakespeare films "would be commercially viable, not overnight, but in the long run" (Brown n. pag.). Throughout this process, it is certainly the case that Mendes was able to draw upon his unique status to make a persuasive case for Shakespeare. Both an Academy Award-winning film director and a renowned theatrical and Shakespearean director, Mendes marries the high cultural world of theatre with the populist world of Hollywood. His personality, career direction, and transnational capacity for moving between London and New York with ease, coupled with this singular facility for working with stage and screen, were all integral to the influence he was able to exercise as the individual in charge of The Hollow Crown initiative. Perhaps only Sir Kenneth Branagh might have been equivalently equipped or successful. It is also possible that Mendes's artistic vision and imprint are noticeable in the connections running across the series as a whole. In many respects, the four films that comprise The Hollow Crown are closely tied, and section one of this essay argues that thematic points of contact illuminate not only the exigencies of funding but also Mendes's credentials as "showrunner" and his recognizable style. However, such points of contact notwithstanding, each of the films examined here bears a further authorial signature. As I argue in section two, this can be accounted for by Mendes's decision to partner with three different directors, namely, Rupert Goold (Richard II), Richard Eyre (the two parts of Henry IV), and Thea Sharrock (Henry V). This essay considers auteurism as an overlapping phenomenon, one that allows for more than one creative approach to be entertained.

In television, of course, the decision to mobilize different directors is not unusual-established directors are regularly invited to direct television dramas in single episodes. (An early example is film director Quentin Tarantino's helming of the "Motherhood" episode in the first season of $E R$ ). Knowing viewers of television, then, are encouraged to recognize a particular director's orientation inside the overall vision of the "showrunner"; indeed, this may be part of a series's appeal. Distinctive about Mendes's specific directorial choices is a theatrical-and Shakespearean-common denominator. The directorial personalities he assembles have all made their names primarily in the theater (although film experience is also evi- 
dent). Hence, Sharrock previously directed As You Like It at Shakespeare's Globe Theatre (2009); Goold, director of the Almeida Theatre, directed Patrick Stewart in a Macbeth production for the Chichester Festival (2007); and Eyre, formerly director of the National Theatre, directed a number of Shakespeare productions, including Hamlet (1989), King Lear (1997), and Richard III (1992), in different venues. ${ }^{1}$ Moving into television, these directors follow in the footsteps of an actor-manager such as Laurence Olivier, who, at a much earlier stage, quickly discovered the symbiotic nature of theater and television as forms that could profitably cross-fertilize. They also suggest a more contemporary illustration of what Jeremy Ridgman identifies as a historically enmeshed and multivalent "relationship between theatre or dramatic performance and the medium of television" (3). As I argue here, the director places his or her auteurial signature on the Shakespearean source material in such a way as to lend each production a unique character; in the same moment, these individualized creative visions unfold in concert with Mendes's conceptualization of the series in its entirety.

The four films that make up The Hollow Crown are packaged-in a manner unique to the televisual medium-as a series. In marketing campaigns, the films are prioritized via an image cluster or triptych that discovers the three kings (Richard II, Henry IV, and Henry V) standing alongside each other, with the particular juxtaposition of leading players working to stimulate viewers to watch all four films, preferably sequentially. The strategy reinforces less a concept of seriality characteristic of television than a "revolution in how we watch"; in one critic's words, box sets now constitute "a significant ... revenue stream" for television companies, while "online streaming, on-demand cable, Netflix, file-sharing, YouTube ... and more" have precipitated a "new mode of television viewing ... compulsive orgies of consumption" (Martin 14). At the same time, the trailer for the series introduces the four films cut and spliced, mixed up and combined, in such a way as to reflect the narrative highlights of each interpretation. As in the rest of the marketing campaign, the trailer advertises the series as a "complete" experience. Indeed, "complete" is highlighted as an onscreen announcement in an underscoring of The Hollow Crown's integrated significance; this is not a collection of parts but an artistic whole to be engaged with in an appropriate manner. The trailer stresses this holistic dimension by directing attention to the connections 
running between the films and the key features - distinctive tones, mood, and palette - of the show to ensue. In this context, it is striking that the trailer sequence is also notable for pointing up both the star quality of the casting and the investment in, and utilization of, British theatrical talent. For example, Rory Kinnear, who plays Bolingbroke in Richard II, is the familiar "director of operations" from Sam Mendes's recent James Bond films, while Tom Hiddleston, who takes the role of Henry V, is more popularly associated with the arch-nemesis figure, Loki, from the Avengers and Thor Hollywood franchise. Both Ben Whishaw (Richard II) and Hiddleston bring to their roles a deep absorption in theater as craft and practice, and they are joined by other stalwarts, such as Patrick Stewart, Simon Russell Beale, Julie Walters, Maxine Peake, John Hurt, and Anton Lesser, suggesting a "Who's Who" of the British theatrical tradition.

Such casting betokens not only Mendes's status as "showrunner" (the mediatized networks he commands and participates in) but also his commitment to theatrical values. Theater is subscribed to, in other words, as an art-form that highlights the seriousness and pedigree of the televisual undertaking. Casting puts at the heart of The Hollow Crown notions of accredited acting and prestige performance. Finessed and individuated performances are foregrounded in major and minor parts, as illustrated in Kinnear's realization of Bolingbroke (his downcast looks, quavering voice, pauses, and discomfort in armor make for a distinctive awkwardness in the royal encounters). Or, one might cite here Julie Walters in the role of Mistress Quickly; her quizzical and querulous delivery exemplifies a subtly understated habitation of the part. With these and other examples, casting accentuates the quintessential "Englishness" of Shakespeare, and not least because the series - typical of national television-makes a point of marshalling the contribution and connections of British theatrical actors. The procedure represents a break with the avowedly multi-national casting methods pursued by the likes of Kenneth Branagh in his Shakespearean cinema; it also contrasts with the notion of a Shakespeare for the world promulgated in the seventy-three multilingual theatre productions staged at Shakespeare's Globe as part of the 2012 cultural Olympiad. ${ }^{2}$ At a further remove, a quality of "Englishness" is detectable not just in the theatrical backdrop to The Hollow Crown but also in the persona of Mendes himself, a practitioner whose association with all things "English" is reflected in awards (from the Directors' Guild of Great Britain) and previous projects (revivals of the musical, Oliver!, and a musical adaptation of Roald Dahl's children's book, Charlie and the Chocolate Factory, are indicative). 
If "Englishness" is mediated through Mendes, then it is simultaneously announced in shooting locations. In addition to a number of Welsh locations, perhaps selected to privilege an idea of authenticity, The Hollow Crown consistently favors English structures and buildings as key architectural elements. These include Gloucester Cathedral (Henry IV), Penshurst Place (Henry V), and Packwood House (Richard II), sites that underscore a period-specific sense of setting. Dominating church interiors are deployed so self-consciously as to bring to mind institutional forms of history, while fortified castles evoke some of the material forms of English heritage. But this is not to suggest a traditionalist heritage emphasis. Rather, settings in The Hollow Crown are sombre and antipathetic, distinguished by tenebrous lighting and generally muted hues. Medieval England, it appears, is not so much golden and refulgent as benighted and dangerous; as a sister television phenomenon such as The Tudors confirms, this palette represents the anti-heritage landscape characteristic of many contemporary reimaginings. It might not appear too great a leap to suggest that Mendes, as "showrunner" overseer of The Hollow Crown, was a contributing factor to the series's perspective. Some of his previous cinematic endeavors play up notes of nostalgia and melancholy (American Beauty [1999]), center on a child's fraught relationship with the violent world of his father (Road to Perdition [2002]), and stress the internally divisive nature of modern-day American imperialism (Jarhead [2005]), illuminating a set of preoccupations that also make themselves felt in Mendes's televisual Shakespearean treatments. An anxious air, for example, pervades the series trailer which, focusing on worried looks, limns an unsettled, chaotic medieval world; the choric chant rising to a crescendo may suggest excitement, but the accompanying close-ups on troubled kingly countenances clarify an overarching logic of uncertainty. The privileging of the three monarchs chimes with a further thematic characteristic of contemporary television drama which is an interest in male characters locked in "unhappy, morally compromised, [and] complicated" situations (Martin 4). But the peculiarly dispiriting contours of the trailer also refract one of the central concerns of Mendes's cinematic career-masculinity in crisis (American Beauty and the more recent Skyfall [2012] are cases in point). Typically, in each of the adaptations in The Hollow Crown, an ailing, challenged, or afflicted king is placed at center stage; individual narratives revolve around this figure, all other elements (such as sub-plots and intrigues) being cast into relief.

In their respective ways, the three film adaptations make of the kingly presence a fundamental ingredient. Hence, in Richard II, the monarch 
is consistently discovered as a focus of attention. In each of the scenes in which he appears, his form functions to elicit engagement. Crucially, Richard is often lensed as a solitary figure, as if having little relation to the other characters (there is a distinctive absence of shots and countershots typical of filmed television dialogue). Still and unmoving, Richard works in iconic ways, not least because he is discovered in terms of visual splendor and spectacular tableaux. Likewise, in Henry $I V$, the titular character, so frequently a slight player or discovered as rather bland in the theatrical record, dominates, and here the performative ferocity of Jeremy Irons — spinning, calculating, and despairing — as the king is key. His seemingly substantial body, enveloped in weighty furs to signify illness, is invariably pictured from the forefront, his interlocutors seen from the back. Beanie-hatted and hunched, Henry IV is, at least in the first half, paradoxically Falstaffian in his broad-shouldered bulk. A comparable strategy is detectable in Henry $V$ in which the youthful monarch appears in the middle of a frame, camerawork accentuating his toned and leatherclad physique as if in recognition of his all-important role.

In a complementary fashion, the adaptations are marked by elaborating studies of men in difficulty. For example, there is the easily distracted and volatile Richard; he smiles but is simultaneously quick to anger, as suggested in the line, "We were not born to sue, but to command" (1.1.196). In the words of Richard Goold, the director, the richly "multi-faceted" nature of the protagonist illuminates how the play celebrates "contradiction in character" (qtd. in Harrison and Tate n. pag.). Cast in a comparable mould is Henry IV: care-worn and guilt-ridden, his torments are spelled out in exasperated enunciations ("some night-tripping fairy" [1H4 1.1.86] is spat out with venom) and a predilection for nail-gnawing. Even Henry $\mathrm{V}$ is equivalently colored, his self-doubting being matched by heroics combined with horrific actions (including, for the first time on screen, the killing of the French prisoners). Characteristically for Mendes, the mises-en-scène of the adaptations highlight not only male forms but the trials to which they are subject. The three kingly bodies are exposed to physical tests, and the concomitant idea of masculinity-in-crisis is given corporeal expression. In Henry $I V$, illness and age propel the king into frailty and insomnia: "And steep my senses in forgetfulness" (2H4 3.1.8) is delivered as a desperate plea, while the parlousness of his condition is suggested in a limping gait, a greyer appearance, and thinner proportions (the furs of before have been abandoned). Henry $V$ opens with a close-up of a corpse (the body of the king in an open coffin), and we return to the scene of a funeral at the close. And, as if in conceptual conversation 
with the staging decision, Richard II also concludes with a corpse that, in a departure from the text, is placed on display; the lid of the coffin is opened so that Richard's decaying and emaciated body is made visible to all. A camera swirl upwards stresses the fact that, in the second half of the adaptation, it is Richard's form to which an audience's gaze is continually directed. As auteur, Mendes exhibits a continuing concern with male bodies in situations of weakness or vulnerability. There is little doubt that Daniel Craig as Bond is imaged as physically and emotionally vulnerable; similarly, in Jarhead, the crack American troops, in H. Louise Davis and Jeffrey Johnson's words, are seen in terms of the "penetrability" of their forms and their own "corporeality" (138). Mendes inscribes himself on The Hollow Crown with a discernible signature and in such a way as to unmoor Shakespeare's histories from any easily identifiable triumphalist emphasis.

Such an interpretive manoeuver is anticipated in the trailer in which the "death of kings" ( $R 2$ 3.2.152) appears as the unifying theme, established via a truncated voiceover version of Richard II's "Let's talk of graves, of worms and epitaphs" address (3.2.141). Operating in this way, the trailer points up the importance to The Hollow Crown of "original" language, and it is assisted in its investments by the speech's content, centered, as it is, on the imperative of telling "stories" (3.2.152). To deliver Shakespeare on television using Shakespearean language is a strategy of a piece with Mendes's casting decisions and invocation of all things "English"; it is also consistent with his Shakespearean choices, past and present, and confirms his ability as a "showrunner" to tackle challenging literary programs. In the same breath, however, the voiceover-and its stress on modes of demise and the consequences of deposition-reinforces a sense of the unpredictability of power, and such a reading comes to the fore when the histories are imagined together as part of a televisual continuum. Even if the speech stops just short of the "hollow crown" (3.2.156) metaphor, which is present only by inference or intertextual foreknowledge, the series concept is undoubtedly matched by the overlaid language. The visuals - carefully filleted narrative moments-are crucial here, for, in order, we witness a proferred sword, the fields of England, a funeral, a beach, a battleground, women laughing, and a coffin. Not only do these imagistic snipets take their cue from Richard II's speech, offering graphic equivalents to references to the "earth" (3.2.143), "death" (3.2.151), "war" (3.2.153), "wives" (3.2.155), and the act of being "murdered" (3.2.156); they also suggest that the dominion that comes with sovereignty is never enjoyed for long. The peculiarly dark palette is sug- 
gestive, as is the soundtrack which, although choric, is marked by basso profundo notes and throbbing drums, with the result that the actions limned are lent a gloomy emotional cast. We are reminded that, with this type of television, a narrative ruthlessness often prevails; in the words of one commentator, there is little in the way of the "catharsis or ... easy resolution in which television had traditionally traded" (Martin 5). We might also recall that, in Mendes's cinematic vehicles, narrative resolutions are hard to come by, reflecting a consistent auteurial trait. In American Beauty, for example, despite a ruminative voiceover, an audience is left with a sense of the meaninglessness of Lester's murder, while in Jarhead, following on from the characters' return home, the victory parade appears as no more than an empty spectacle. So do these previous projects offer contexts for Mendes's auteurial conception of Shakespeare and affirm an elaboration of the histories as open explorations of the evanescence of authority.

\section{II}

Even if an overraching conception of the histories remains constant, and notwithstanding the utilization of the same production team across the series, the decision to change directors - to assign each adaptation an individual interpreter-means that the films that comprise The Hollow Crown simultaneously represent distinctive works of imagination. Inside a Mendes template, the directors pursue complementary but very different design choices. If Mendes makes the blueprint available and sets the tone, he also gives space to Eyre, Goold, and Sharrock to develop their own visions and provides the conditions within which other Shakespeares might unfold. Essential in this connection, is the fact that each director either writes or co-writes the screenplay. As is often the case in television adaptation, this means that these directors have a double stake in the enterprise. Thus, Richard II is written by Rupert Goold, Ben Power, and William Shakespeare; Henry IV is credited to Richard Eyre and William Shakespeare; and Henry $V$ is presented as the work of Thea Sharrock and William Shakespeare. Notably, each Shakespearean collaboration is distinct. The textual method of Goold's Richard II is to edit out entire descriptive passages, to interpolate action sequences, to rearrange scenes, and to downplay women's contributions (the Duchess of Gloucester is omitted, while Richard's Queen is allowed a less prominent role). By contrast, Eyre generally retains the basic shape of the plays in his Henry $I V$; his preference is for splicing, trimming, and rearranging within scenes, 
often at the cost of the comedy. Consequently, and not least because, in the second part, Falstaff's soliloquies are cut in their entirety, Henry IV impresses as a historical drama infused with a greater generic gravitas. Sharrock's controversial cuts include the traitors' scene, the four captains' scene, and several of Henry's major speeches. This Henry $V$, like its Olympian sporting counterpart, constitutes a team effort, and its concomitant narrative thrust is angled towards the knitting together of its multivalent constituencies.

In keeping with discrete textual judgements, each of the films in The Hollow Crown is characterized by a uniquely rendered vision or aesthetics. According to Richard Goold, the aim in Richard II is to convey an "evangelical" personality in such a way as to point up the play's "poetic sensibility" (qtd. in Harrison and Tate n. pag.). As Lindsey Scott notes, Goold works productively with Shakespearean language: the "images" that fill "the screen," she writes, "illuminate rather than detract from the play's poetry" (108). The visual orientation has precedent, for, in his production of Macbeth for the Chichester Festival, Goold consistently directed attention to the up-and-down movements of an onstage elevator (a metaphor for the entrance to hell), and, dressing the witches as nurses, aimed at suggesting parodically caring "sisters." As far as Richard II is concerned, a particular lensing of the protagonist is manifested via frontal lighting, the king appearing more brightly than those around him. In part such distinctions are assisted by color decisions. Richard is palely adorned and accoutred; he wears mainly yellow or white flecked with gold braid; and he is surrounded by golden instruments and accessories, such as an orb and scepter. (The figuration contrasts notably with the hues used for Richard's enemies, for, in the episodes in which they appear, a dun palette made up of blues, browns, and greys marks them out as initially malignly disaffected and alienated). Yellow or gold continue to operate as Richard's signature, as 3.2, the scene of his return from exile (his orange robes complement the beach's yellow sands), and 3.3, the scene before Flint Castle, indicate. Here, an elaborate tableau consisting of a gold-armored Richard and cut-outs of a sun and clarion-calling angels suggests the ways in which the king has orchestrated a dazzling pageant of his own devising. A soft-focus close-up on his eyes and crown soon gives way to a wide-angle upward-looking shot of the monarch on the battlements, confirming that, as much as Richard controls the spectacle, he also shapes how he is to be looked at. At once, the adaptation's predilection for color coding recalls the play's absorption in gilded analogies. The sun's "golden beams to you here lent / Shall point on me and gild 
my banishment" (1.3.140-41), exclaims Bolingbroke bitterly, his analogy finding support in the scene of his dismissal, a stately pleasure tent made up of yellow-orange drapes that flutter in the breeze. Bolingbroke's later description of Richard appearing "As doth the discontented sun / From out the fiery portal of the east / When he perceives ... envious clouds" (3.3.62-64) is cut, remaining only in the vestigial gestural indicator, "See" (3.2.61), yet the king's anger, and his association with all things sun-like, are clearly apparent in his Flint Castle performance. At this point, as at others, the production's visual landscape surrogates for verbal omissions.

Further underscoring the utility of Goold's visual engagement with Richard II is the way in which costuming becomes inseparable from the protagonist's subscription to a theory of "divine right." In the forced deposition scene, for instance, Richard is represented barefoot and attired in a flowing white robe; opening his arms wide, he impersonates the figure of Christ on the cross, suggesting in his actions the condition of martyr. Crucially, the adaptation retains the line that testifies to the protagonist's conviction of his own status- "Not all the water in the rough rude sea / Can wash the balm from an anointed king" (3.2.51) — and also makes a point of accentuating the two Richard-Christ comparisons. ${ }^{3}$ Strikingly, although clothes are gradually stripped away, dress still functions to stress the king's Christ-like affiliations. Hence, when Richard is removed to the Tower, he is reduced to wearing the briefest of white loin-cloths, but here the iconic image of the crucifixion reverberates, not least due to shots of white doves and the welcoming gesture with which he greets the arrows that pierce his form. At this point, a further martyrological connection is introduced, the scene harking back to the start in which Richard is seen touching a young man who models Saint Sebastian for an artist. The meshing of the two moments hints both at Richard's premonition of his own fate and at a complicating homoeroticism to his fall from grace. At the very close, as Richard's barely covered body is exposed in the coffin, the camera rises upwards to contemplate a suspended statue of the crucified Christ. Goold's conceptual framing as auteur, a commitment to the implications of color, and a will to analogize the play's poetry-all can be traced in an ascending movement that transports us from the earthly to the sublime. ${ }^{4}$ Yet, at the same time, as the adaptation's gaze rests on Christ's golden halo offset by the surrounding black, a key moment in which familiar visual polarities are finally brought together, the implication is that the gilded and divinely-inspired world that has been Richard $I I$ exists in a symbolic realm only and that a bleaker and more ineluctable darkness is the political reality. 
If Goold's auteurial vision centres on the translation of Shakespearean thematics into visuals, Richard Eyre's revolves around his conception of parts one and two as a single entity. Explains Eyre, "I have always thought of parts one and two" of Henry $I V$ as "the same story, so we shot them out of sequence," allowing "Jeremy and Tom to have the arc of their relationship in mind throughout" (qtd. in Harrison and Tate n. pag.). Key to his sense of the continuum is the vexed connection between Henry and Hal, king and prince, father and son. This becomes the nexus of the interpretation, Hal's roistering with Falstaff being cast into the shade. ${ }^{5}$ An early example of father-son foregrounding is the scene in open court. "Lords, give us leave," states Henry wearily, as if bracing himself for a conversation he has had many times (1H4 3.2.1); reinforcing the idea of a communication impasse is the way $\mathrm{Hal}$, in response, sighs, rolls his eyes, and interrupts his father (his "So please your majesty" [1H4 3.2.18] is brought forward) in a generationally impatient fashion. "I shall hereafter, my thrice-gracious lord, / Be more myself" (1H4 3.2.92-93) is delivered sarcastically, and Henry's response to the lines-he slaps his son around the face-succinctly encapsulates the idea of a relationship that has broken down at every level. During this sequence, events are seen "principally through [Henry IV's] eyes"; as Rosemary Gaby writes, "narrative structure and mise-en-scène are aligned with [his] perspective" (239). The effect is to underscore the anguish of a father attempting to come to terms with his recalcitrant offspring and to play up the long-standing pain of the paterfamilias.

Intriguingly, as part two progresses, the perspective is reversed, and nowhere more so than in 4.3 , the extended dispute over possession of the crown. This episode takes precedence; it overshadows the rejection of Falstaff and it facilitates the location of sentiment firmly in the family (at the opening, in which Henry IV confers with three of his sons, and in 5.2, in which the new king addresses his brothers, a similar sensibility is apparent). Typical in 4.3 is the way in which $\mathrm{Hal}$, whose point of view is now privileged, is pictured kneeling at the side of the monarchical bed; at the reference to "filial tenderness," he leans forward to kiss his father's head, suggesting a desire for reconciliation (4.3.169). Via this readjustment to the emotional core of Henry $I V$, Eyre might be said to have been addressing some of his own demons. In his autobiography, he investigates what one commentator has described as "an agonizing sense of mutual incomprehension between father and son," while directing a stage production of King Lear appealed, it has been suggested, precisely because of the play's overriding concern with "the tyranny of fatherhood" 
(Dickson n. pag.). In 4.3's series of tussles around the crown and throne, such a conflict between father and son is made manifest in the blocking and spatial choreography of the scene. For if, at one moment, the king occupies the royal seat, Hal sitting at his feet, in a later moment, the roles are reversed, with the prince now assuming the more elevated position. Personal dynamics are written across the "golden rigol" (4.3.166), and, when Henry and Hal finally unite, it is their mutual handling of the crown that signifies a familial rapprochement. Only when personal grievances have been aired can a new political dispensation, and the unqualified recognition of Hal as heir apparent, be inaugurated. So it is that the sequence stresses the point at which Henry places the crown on Hal's head, the informal coronation operating to resolve paternal-filial tensions. Too, a personal dimension inheres in the repositioning of Henry's reflection, "How I came by the crown, O God forgive, / And grant it may with thee in true peace live!" (4.3.346-7). Now placed to indicate the close of the meeting, the lines work to point up not only a sense of Henry's own guilt but also the desire for his trials and tribulations to cease: his final thoughts are with $\mathrm{Hal}$ and with the trauma of a troubled inheritance. Lending emotional emphasis is the fact that Henry dies in honoring $\mathrm{Hal}$; the transfer of power ends the process of reconciliation, the king's injunction to "live" being ironically counterpointed by his own demise. Eyre brings to Henry $I V$ a singular vision of the two plays operating as one; he also imagines and focuses the Shakespearean work in the light of inner thematics.

In contradistinction with Henry $I V$ and its stress on the adult male point of view, Thea Sharrock, helming the first female interpretation of Shakespeare's "star of England" (Epilogue.6), places the perspectives of women and children at center stage. It is a characteristic approach for a director who has supported the work of female playwrights such as Caryl Churchill, Lucinda Coxon, and Yasmina Reza, and who, additionally, has been drawn to drama that makes a virtue of women's experience. (In 2003, for instance, Sharrock directed Ibsen's $A$ Doll's House for the Southwark Playhouse, and this was followed up by her 2007 production of Churchill's Cloud 9 in which British colonial history is debated via a playful engagement with issues of gender and sexuality). Typical of Sharrock's method is Henry $V_{\text {s }}$ interpolated opening which makes manifest the play's epilogue by presenting Henry V's funeral. The film begins with a shot of a child plucking a flower from the ground, immediately establishing themes of passing, innocence, and loss. Giving priority to point of view, the action of the scene is mediated through the eyes of this child and subsequently 
through the eyes of Katherine (glimpsed in mourning garb processing as part of the funeral procession). The effect is to establish an intimacy between two key interpretive personalities, the alliance being cemented in the gesture of the child; he throws his flower towards the queen, and Katherine's sympathetic glance towards him hints at an underlying rapport. Throughout this film, woman and child operate as reliable readers and spectators, offering a felt responsiveness to a world of heroism previously construed only in masculine terms.

Because we see the funeral through Katherine's eyes, it is represented as a personal and familial rather than a dynastic tragedy. Eloquent in this connection are the loving looks bestowed by the princess on the corpse and the giddy $180^{\circ}$ camera pan which mimics her grief and disorientation. $\mathrm{Via}$ a self-conscious montage, the production retrospectively constructs the Henry-Katherine relationship as a love match, preemptively diffusing the later difficulties of staging 5.1 (the wooing scene). The sense that this is a tragedy belonging in the first instance to Henry's nuclear family is strengthened by the appearance here of a character only mentioned in the epilogue- "Henry the Sixth" — for, behind the spectating widow, a waiting-woman is seen carrying a vulnerable new-born in "infant bands" (Epilogue.9). Re-envisioning a play that notoriously downgrades women, the interpolation characteristically amplifies Katherine's significance, and her contribution is accentuated throughout. The scenes involving Katherine, often trimmed in production, are played in full. Also suggestive are extensions to her role. As well as the opening scene, Katherine is represented in the background to several exchanges, granting her an additional weight and symbolic visibility and conjuring her as a silent onlooker possessed of intelligence.

On the battlefield, comparable functions reside with Falstaff's Boy, confirming the opening premise that women and children form an important interpretive collective. Initially, the Boy is emblematic of those who, with "one appearing hair ... follow" the king's "culled and choice-drawn cavaliers" (3.Chorus.23-24), but, as the action develops, he is privileged as spectator and interpreter. He consistently appears in the margins of the mise-en-scène: war and its attendant horrors are communicated through his gaze, meaning that there is little of the traditional distance between theatrical and cinematic verisimilitude. And, while most of his lines are cut (including the long speech at 3.2.27-49), the Boy's role is simultaneously developed by being merged with that of the Chorus, with the end of the film revealing the Boy as the Chorus's retrospective viewpoint. Interestingly, Sharrock breaks with the tradition of staging the Boy's 
death; uniquely, he is kept alive as the last survivor of the French campaign. Foregrounding an alternative set of perspectives, Sharrock stresses the costs of war, reining back the play's traditionalist associations and deemphasizing the nationalist identifications of Shakespeare's most infamous nationalist statement. The result is to underscore the implications of a final instalment which puts women and children - removed by both Goold and Eyre-firmly back into Shakespeare's historical world-view.

\section{Conclusions}

In the trailer for The Hollow Crown, as might be anticipated, particular attention is reserved for images of crowns, whether they are placed on kingly heads, offered or removed, the idea being that the royal diadem occupies a charged place in the historical process. An index of power and hollowness, the crown is consistent with Mendes's auteurial vision for the history cycle, but, interestingly, as property and symbol, it recurs in very different applications across the three adaptations, suggesting the multiple ways in which a unitary conception can percolate downwards to ignite individual interpretations. Most obviously, crowns in The Hollow Crown are uniquely fashioned: Richard II's is a rising, jewel-encrusted and fancily wrought piece, Henry IV's is a squatter expression of royalty, decorated with oak leaves, and Henry V's version is more plainly adorned still, although rimmed with crosses. Each of these prized possessions announces the personality of its owner (and broad themes touching upon aspiration, the natural world, and religion) and bears witness to the practices and perspectives of the adaptations' creators. Furthermore, each crown is subject to contrasting uses. In Richard II, the protagonist rolls his crown across the floor so that it ends at the embarrassed Bolingbroke's feet; throwing the scene into relief is Henry $I V$ in which a crown is a familial object to be fought for and appropriated. And, in Henry $V$, again distinctively, the crown operates either as a prop or as an inconvenience to a monarch driven to legitimize his masculinity at court and on the battlefield. The overarching motif of the series, the crown is made visible in such a way as to tease apart the relations between Shakespeare, a nostalgic sense of England, and the will to make nation - and commemorate heritage - in the twenty-first century. No less eloquently, it serves to illuminate how one auteur's invention can cross-fertilize with another's, generating diverse engagements inside a larger televisual experience. This, then, is the newer model that is transforming an appreciation of Shakespeare for the modern viewer, and, as the 2016 season of The Hollow Crown makes clear, 
similar strategies of conception, choice, and individual creation continue. ${ }^{6}$ The notion that a single, controlling figure - a primary artist - carries on his or her shoulders the weight of a show's success or failure is overly simplistic. But the alternative - that of the blurred paradigm of collaboration-is also flawed, especially in the case of Shakespeare on television. Rather, what is demonstrated by The Hollow Crown is a complex interplay between a "showrunner" and a range of practitioners who take on board a variety of responsibilities so as to revivify Shakespeare's work for a changing art-form. ${ }^{7}$

\section{Notes}

${ }^{1}$ The Macbeth production was later adapted for the screen and shown on BBC4; King Lear was similarly adapted and shown as part of the BBC/PBS "Performance" series.

${ }^{2}$ For pertinent discussions, see Edmonson, Prescott, and Sullivan; and Bennett and Carson.

${ }^{3}$ These are, respectively, the lines "So Judas did to Christ" (4.1.161) and "you Pilates / Have here delivered me to my sour cross" (4.1.230-31).

${ }^{4}$ The transition heavenwards is supported by the ecclesiastical setting: the nave of St David's Cathedral, Pembrokeshire.

${ }^{5}$ Interestingly, from an early point, there is every indication that Falstaff and Hal will grow apart, and not least as this is intimated in an interpolated episode at the battle of Shrewsbury, the older knight refusing to come to the younger prince's aid.

${ }^{6}$ Mendes retains executive auteurial control of the second series (adaptations of Henry VI and Richard III), using again the cream of British theatrical talent, drawing upon the resources of individual directors (Dominic Cooke) and investing in established heritage locations.

${ }^{7} \mathrm{My}$ thanks to Greg M. Colón Semenza for suggesting this topic and for his astute comments on an earlier draft.

\section{Works Cited}

American Beauty. Dir. Sam Mendes. Perf. Kevin Spacey. DreamWorks SKG, 2012. DVD.

Bennett, Susan, and Christie Carson, eds. Shakespeare Beyond English: A Global Experiment. Cambridge: Cambridge UP, 2013. Print.

Brown, Maggie. "Sam Mendes: BBC Worldwide rejected Hollow Crown Shakespeare Films." The Guardian. 2 July 2012. Web. 30 Nov. 2015.

Coward, Rosalind. "Dennis Potter and the Question of the Television Author." Film and Theory: An Anthology. Ed. Robert Stam and Toby Miller. Oxford: Blackwell, 2000. 7-15. Print. 
Davis, H. Louise, and Jeffrey Johnson. "One Nation Invisible: Unveiling the Hidden War Body on Screen.” The War Body on Screen. Ed. Karen Randell and Sean Redmond. London: Continuum, 2008. 134-146. Print.

Dickson, Andrew. "A Life in Theatre: Richard Eyre." The Guardian. 29 Nov. 2010. Web. 15 Dec. 2015.

Edmonson, Paul, Paul Prescott, and Erin Sullivan, eds. A Year of Shakespeare: Re-living the World Shakespeare Festival. London: Bloomsbury, 2013. Print.

Gaby, Rosemary. "The days that we have seen': History and Regret in Henry IV, Parts One and Two, The Hollow Crown." Shakespeare and Emotions: Inheritances, Enactments, Legacies. Ed. R. S. White, Mark Houlahan, and Katrina O'Loughlin. Basingstoke: Palgrave, 2015. 231-240. Print.

Harrison, Phil, and Gabriel Tate. "Interviews: The Hollow Crown." Time Out: London. Web. 22 Jan. 2014.

Henry IV. Dir. Richard Eyre. Perf. Jeremy Irons. BBC/Universal/Neal Street/ WLNC, 2012. DVD.

Henry V. Dir. Thea Sharrock. Perf. Tom Hiddleston. BBC/Universal/Neal Street/ WLNC, 2012. DVD.

Jarhead. Dir. Sam Mendes. Perf. Jake Gyllenhaal. Universal, 2005. DVD.

Martin, Brett. Difficult Men: Behind the Scenes of a Creative Revolution. New York: Penguin Books, 2013.

“Showrunner." Def. 2. OED Online. Oxford UP, June 2016. Web. 8 June 2016.

Richard II. Dir. Rupert Goold. Perf. Ben Whishaw. BBC/Universal/Neal Street/ WLNC, 2012. DVD.

Ridgman, Jeremy. Introduction. Boxed Sets: Television Representations of Theatre. Ed. Jeremy Ridgman. Luton: John Libbey Media/Arts Council of England, 1998. 1-10. Print.

Road to Perdition. Dir. Sam Mendes. Perf. Tom Hanks. DreamWorks SKG/ Twentieth-Century Fox, 2002. DVD.

Robertson, Colin. "Mad Men, True Detective and the Rise of the TV Auteur." The List. 9 Apr. 2004. Web. 5 Nov. 2015.

Scott, Lindsey. "Review of The Hollow Crown (directed by Rupert Goold, Richard Eyre and Thea Sharrock), BBC Two, 30 June-21 July 2012." Shakespeare 9.1 (2013): 108-114. Print.

Shakespeare, William. The Norton Shakespeare. Ed. Stephen Greenblatt, Walter Cohen, Jean Howard, and Katharine Eisaman Maus. New York: Norton, 1997. Print.

Skyfall. Dir. Sam Mendes. Perf. Daniel Craig. Eon Productions, 2012. DVD.

Stam, Robert. "The Author." Film and Theory: An Anthology. Ed. Robert Stam and Toby Miller. Oxford: Blackwell, 2000. 1-6. Print. 